\title{
Geophysical evidence of the 1912 earthquake rupture along the central fault system of the Acambay Graben, Central Mexico
}

\author{
Evidencias geofísicas de la ruptura del sismo de 1912 a lo largo del sistema de fallas central del \\ Graben de Acambay, Centro de México
}

Pierre Lacan ${ }^{1, *}$, Claudia Arango-Galván ${ }^{2}$

${ }^{1}$ Centro de Geociencias, Universidad Nacional Autónoma de México, Blvd. Juriquilla, 3001, 76230, Juriquilla, Querétaro, México.

${ }^{2}$ Instituto de Geofísica, Universidad Nacional Autónoma de México, Circuito de la Investigación Científica S/N, Ciudad Universitaria, 04510, Giudad de México, México.

* Corresponding author: (P. Lacan)

placan@geociencias.unam.mx

\section{How to cite this article:}

Lacan, P., Arango-Galván, C., 2021, Geophysical evidence of the 1912 earthquake rupture along the central fault system of the Acambay Graben, Gentral Mexico: Boletín de la Sociedad Geológica Mexicana, 73 (2), A250121. http://dx.doi.org/10.18268/ BSGM2021v73n2a250121

Manuscript received: September 15, 2020 Corrected manuscript received: December 10, 2020 Manuscript accepted: January 23, 2021

Peer Reviewing under the responsibility of Universidad Nacional Autónoma de México.

This is an open access article under the CC BT-NC-SA (https://creativecommons.org/licenses/by-nc-sa/4.0/)

\section{ABSTRACT}

In this work, we have applied two geophysical techniques in two different areas of potential interest for paleoseismological assessment of the active faults of the Acambay graben. The main goal was to localize segments of buried faults suspected to break the surface during the 1912 Acambay Earthquake, in order to (1) identify favorable sites for paleoseismological investigation purpose and (2) extrapolate the data obtained with a paleoseismic trenching. On the one hand, Electromagnetic Induction (EMI) Method was used to map the horizontal variation of the apparent resistivity in order to detect the 1912 surface rupture of the Temascalcingo fault in the alluvial plain of the Lerma River. On the other hand, within a volcanic edifice, the Electrical Resistivity Tomography (ERT) technique was used to characterize the electrical resistivity distribution along a profile in order to detect and localize the San Pedro fault, partially buried in a Holocene sedimentary filling of a small endorheic basin. Results of these studies allow defining location and orientation of the structures that potentially broke the surface during the 1912 earthquake and are partially hidden by recent deposits filling the tectonic depressions. Good correlation between ERT subsurface to deep imagery of faults and a trench survey which cuts across the San Pedro fault trace, illustrate the pertinence to use such techniques for paleoseismological investigation purpose in volcano-sedimentary environments.

Keywords: active fault, geophysical characterization, electrical resistivity tomography, electromagnetic induction, paleoseismology, Temascalcingo fault, San Pedro fault.

\section{RESUMEN}

En este trabajo, aplicamos dos técnicas geofisicas en dos áreas diferentes de potencial interés para la evaluación paleosismológica de las fallas activas del graben de Acambay. El objetivo principal es localizar dos segmentos de fallas parcialmente anegadas por la sedimentación que posiblemente rompieron la superficie durante el terremoto de Acambay de 1912, para (1) identificar sitios propicios para fines de investigación paleosismológica y (2) extrapolar los datos encontrados en excavación paleosísmica. Por un lado, se utilizó el método de Inducción Electromagnética (EMI por sus siglas en inglés) para mapear la variación horizontal de la resistividad aparente con el fin de localizar en subsuperficie la ruptura de 1912 de la falla Temascalcingo en la llanura aluvial del río Lerma. Por otro lado, dentro de un edificio volcánico se utilizó la técnica de Tomografia de Resistividad Eléctrica (ERT por sus siglas en inglés) para caracterizar la distribución de resistividad eléctrica a lo largo de un perfil con el fin de detectar y localizar la falla San Pedro parcialmente sepultada por un relleno sedimentario holoceno en una pequeña cuenca endorreica. Los resultados de estos estudios permiten definir la ubicación y orientación de las estructuras que rompieron potencialmente durante el terremoto de 1912 y están parcialmente ocultas por depósitos recientes que llenan las depresiones tectónicas. La buena correlación entre las imágenes ERT del subsuelo y un levantamiento en trincheras cortando la traza de la falla de San Pedro, ilustra la pertinencia de usar tales técnicas para complementar la investigación paleosismológica en ambientes volcánico-sedimentarios.

Palabras clave: falla activa, caracterización geofísica, tomografía de resistividad eléctrica, inducción electromagnética, paleosismología, falla Temascalcingo, falla San Pedro. 


\section{Introduction}

The study of earthquake-related surface ruptures is essential to understand the modalities of faulting and evaluate the seismic hazard. Likewise, knowledge about recent earthquake ruptures is indispensable analogues for the interpretation of the geological recording of paleoseismological deformations (e.g. Fletcher et al., 2014; 2020). In central Mexico, the Trans-Mexican Volcanic Belt (TMVB) is crossed by different fault systems whose activity is revealed by the occurrence of several destructive historical seismic events (e.g. Suárez et al., 2019). The 1912 Acambay Earthquake is the last event with an associated surface rupture to have been properly described in the TMVB (Urbina and Camacho, 1913). This event can therefore allow us better understanding the rupture and deformation style in this area. Unfortunately, inaccuracies and contradictions between the effects of the earthquake reported in the text and maps by Urbina and Camacho (1913) resulted in different interpretations of the rupture by the scientific community (Suter et al., 1995; Langridge et al., 2000; Rodríguez Pascua et al., 2012; 2017). To remove uncertainties regarding the mapping and the nature of the ruptures, paleoseismological studies were undertaken to characterize the activity of the different fault segments and specify the faults involved in the 1912 earthquake.

Paleoseismology looks for sedimentary records of ancient earthquakes. In practice, trenches are excavated across faults escarpment, in areas where the balance between erosion and sedimentation is adequate to have recorded the last seismic events (McCalpin, 2009). In such investigations, shallow geophysical imaging is sometimes essential to solve some problems related to the trenching technique. In the first place, before the excavation, geophysical imagery could be used as a reconnaissance tool in buried fault area, or areas with diffuse deformations, to image shallow structures and locate the better sites for further trenching (e.g. Aray Castellano et al., 2021). Otherwise, geophysical imaging is also useful for tracing faults to depths greater than can be reached by trenching $(>5-6 \mathrm{~m})($ e.g. La Femina et al., 2002; Wolf et al., 2006; McCalpin, 2009; Bonorino et al., 2012; Lacan et al., 2012; Gally and Piscitelli, 2014; Arzate et al., 2018). For their low cost and ease of use, Ground Penetrating Radar (GPR) and seismic reflection are the most common geophysical techniques employed for these purposes (e.g. Stephenson and McBride, 2003; Audemard et al., 2006; McCalpin, 2009) while in volcanic environments, the geophysical signatures of faults resulting from physical contrasts between sedimentary fill and surrounding strongly magnetized lava flow are easily observable with potential-field and electrical methods. However, the trend is towards integrating geophysical data from different techniques (e.g. Nguyen et al., 2005; Cinti et al., 2015; Villani et al., 2015, Villani and Sapia, 2017; Onorato et al., 2019).

This paper deals with other two very accessible geophysical techniques already used as reconnaissance tool for paleoseismological characterization since the acquisition can be fast, inexpensive and efficient to locate and establish the geometry of the fault zone: The Electromagnetic Induction (EMI) method and the Electrical Resistivity Tomography (ERT) (e.g. La Femina et al., 2002; Nguyen et al., 2005, 2007; Fazzito et al., 2009; Terrizzano et al., 2012). We present here the results of the two studies that we perform on the Acambay Graben in order to localize buried paleosurface rupture and complete paleoseismological studies. Firstly, EMI has been used to localize the Temascalcingo fault, locally buried in an alluvial plain. Subsequently, within a volcanic edifice, ERT has been applied to image the geometry at depth of the San Pedro fault closing a small endorheic basin.

\section{Geological setting and related issues}

The central region of Mexico is an example of an intracontinental volcanic zone in which the activity of faults has led to historical destructive earthquakes despite apparently low instrumental seismicity (e.g. Suárez et al., 2019; Zúñiga et al., 
2020). All these earthquakes were produced by faults located within the Trans-Mexican Volcanic Belt (TMVB), a middle Miocene to Quaternary arc related to the subduction of the Cocos and Rivera plates beneath the North American plate (e.g. Demant, 1978; Nixon, 1982; Siebe et al., 2006; Ferrari et al., 2012; Figure 1). In the central part of the TMVB, extensional faulting is accommodated through the Morelia-Acambay Fault System (MAFS) that stretches over $200 \mathrm{~km}$ in length and up to $50 \mathrm{~km}$ in width (Figure 1B; Johnson and Harrison, 1990; Suter et al., 1995). The MAFS is characterized by NNE to NNW directed active extension at low rates $(<0.3 \mathrm{~mm} / \mathrm{a}$; Suter et al., 2001; Langridge et al., 2000). The Acambay Graben is one of the major intra-arc basins of the MAFS in which occurred the November 19, 1912 Mw 7.0 Acambay earthquake (Figure 1; Urbina and Camacho, 1913; Abe, 1981; Suter et al., 1996; Langridge et al., 2000). This event caused loss of life, extensive damage and surface rupture along different faults of the graben. The social, architectural, as well as the geological effects, have been meticulously identified and reported by Urbina and Camacho (1913). However, some important discrepancies exist between the descriptions made in the text and the surface ruptures map presented in this report as well as errors in the mapping, mostly related to the tools used at the time. These inaccuracies result in different maps and interpretations of the rupture published in recent years as summarized in figure 2 (Suter et al., 1995; Langridge et al., 2000; Rodriguez Pascua et al., 2012; 2017). In detail, the description of the ruptures occurring along the faults bordering the graben is precise and there are no major discrepancies about their mapping and interpretations, however, the precise location and nature of the surface ruptures on the central faults of the graben are subject to more controversy (Figure 2). The descriptions of cracks and ruptures are relatively precise in the manuscript by Urbina and Camacho (1913)

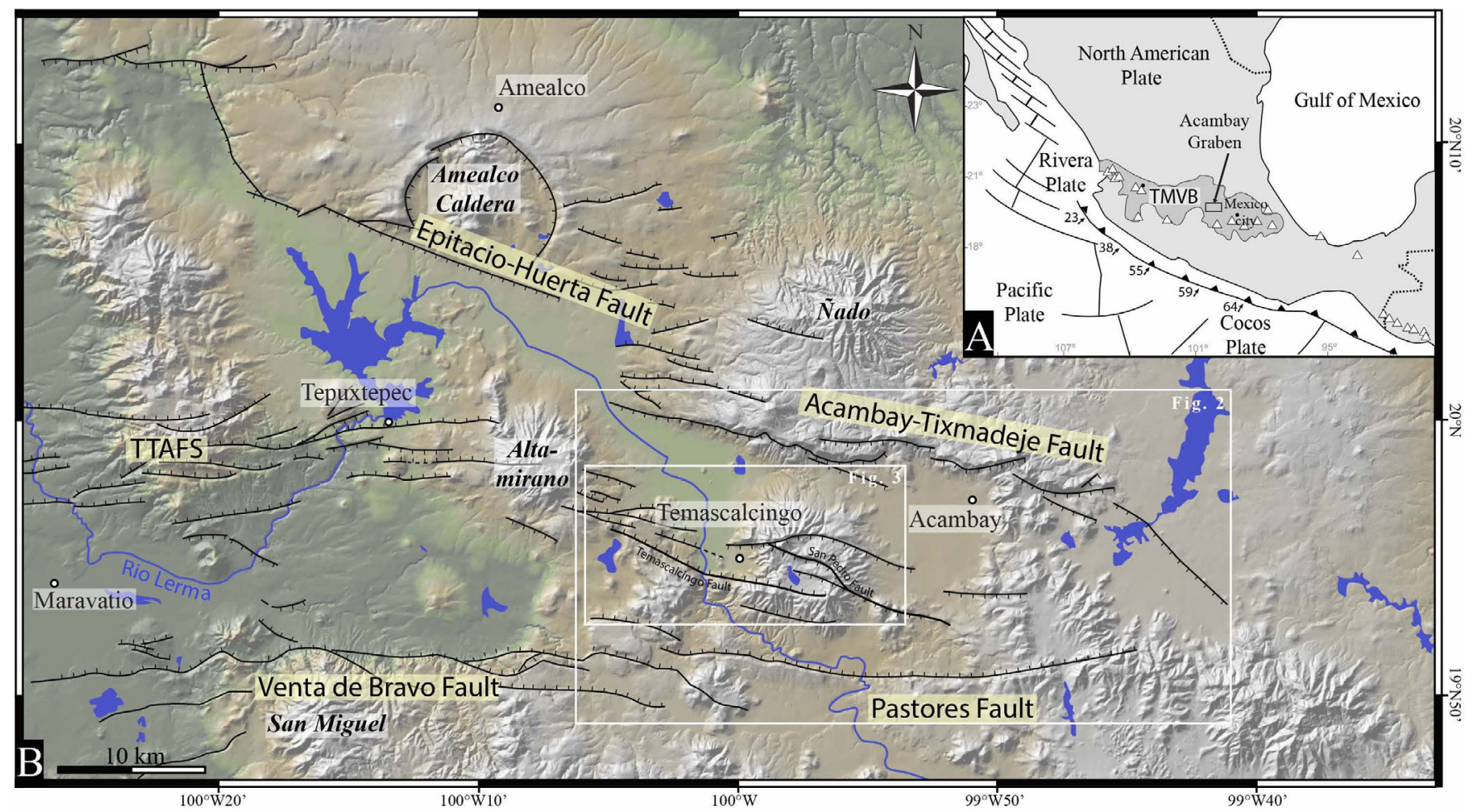

Figure 1 (a) Geodynamic location of the Trans-Mexican Volcanic Belt. (B) Tectonic map of the Acambay Graben. TMVB: Trans-Mexican Volcanic Belt; TTAFS: Tepuxtepec-Temascalcingo-Acambay Fault System. Modified from Lacan et al. (2018). 30-m-resolution digital elevation model derived from GeoMapApp. 
in and around the town of Temascalcingo. However, maybe for lack of accessibility at that time, written descriptions are more sporadic away from the town of Temascalcingo and only an imprecise schematic map reports surface deformations which could correspond to tectonic ground ruptures or superficial cracks linked to shaking in the central Acambay graben (Figure 2).
Since the beginning of the 21 century, different paleoseismic studies have been carried out in order to characterize the seismic hazard parameters of the major faults of the Acambay graben (Langridge et al., 2000, 2013; Lacan et al., 2013a, 2018; Sunye-Puchol et al., 2015; Ortuño et al., 2015, 2019). The uncertainties for most of these studies have been estimated in order to integrate them
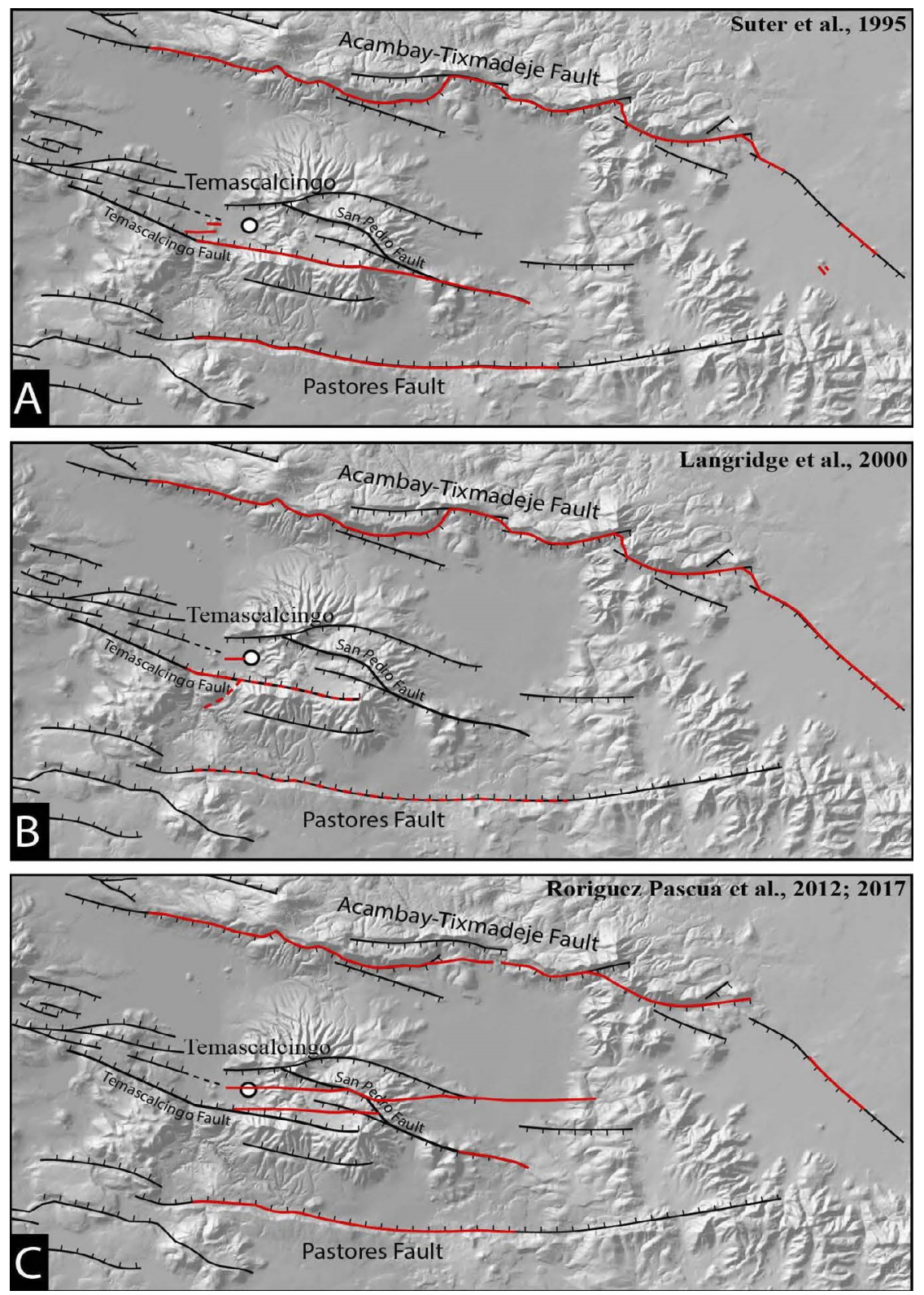

Figure 2 The 1912 earthquake rupture map of the Acambay Graben according to (A) Suter et al. (1995); (B) Langridge et al. (2000); (C) Rodriguez Pascua et al. (2012; 2017). The red continuous lines indicate the deformations interpreted as being surface breaks of tectonic origin while the red dotted lines indicate the deformations interpreted as cracks in the ground. 30-m-resolution digital elevation model derived from GeoMapApp. 
in seismic hazard analysis (Rodríguez-Pérez et al., 2017). The implementation of such paleoseismic investigation is necessary but sometimes difficult due to the geological context. Since the beginning of its opening during Miocene time, the Acambay Graben is filled by a series of volcanic deposits and lacustrine sediments sometimes overlapped by volcanic edifices and flows. The geomorphological footprint of the faults is very clear on volcanic rocks and lava flows but unclear or non-existent in recent sedimentary fillings where trenching is essential for paleoseismic research (Figure 3). The precise location of faults in the sedimentary cover is then the first challenge that arises before undertaking a paleoseismological study.

Another challenge comes to light after the opening of a trench to extrapolate the geometry of the fault in depth. Indeed, the trench allows only seeing the fault on its superficial geometry which can be different from its geometry in depth. In fact, its superficial geometry can be influenced by the weakness of vertical forces and not be consistent with its geometry at depth (McCalpin 2009).

Next, we show how EMI and ERT geophysical methods, inexpensive and easy to set up and modelling, allowed solving these challenges.

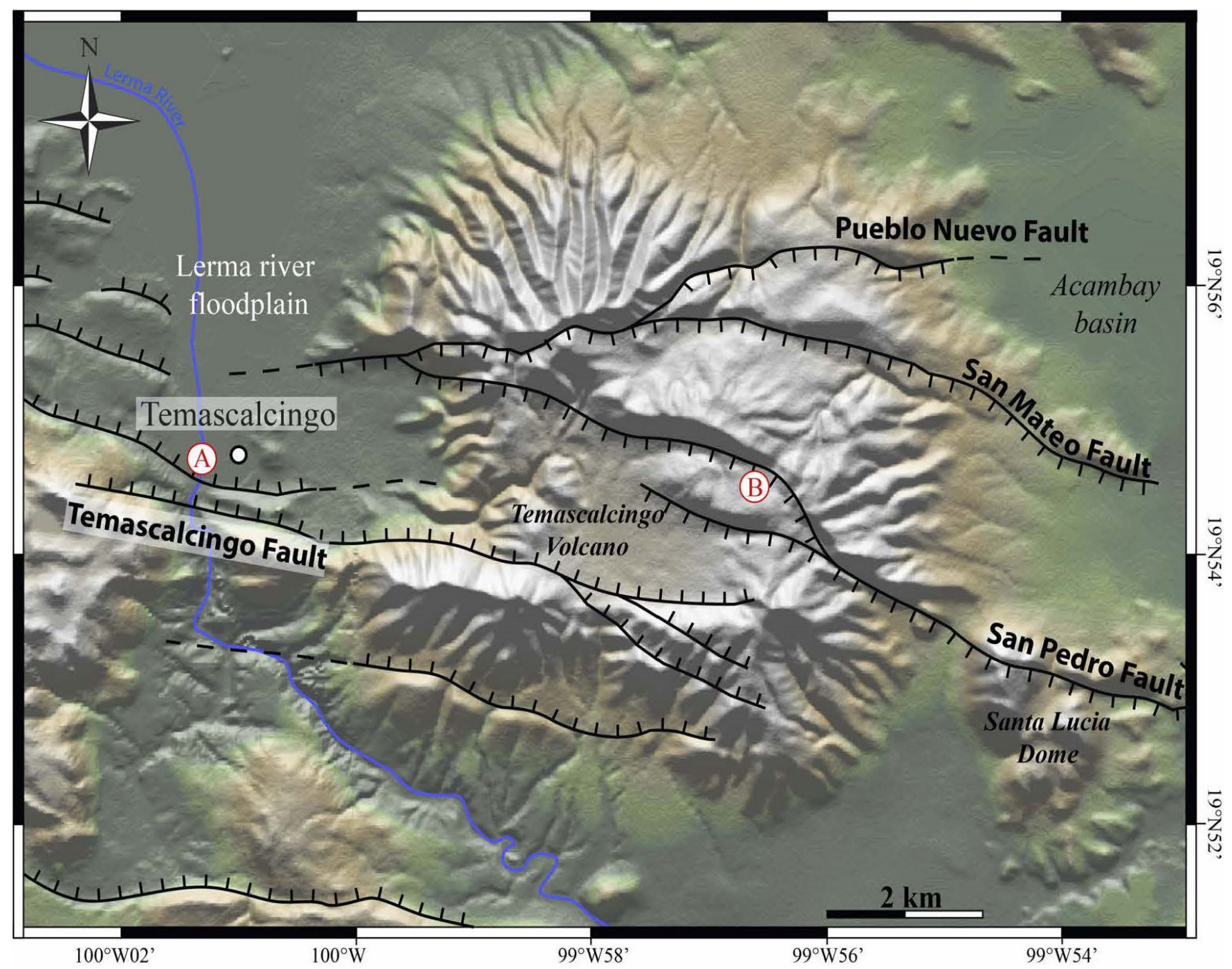

Figure 3 Tectonic map of the Temascalcingo Volcano with location of the Temascalcingo (A) and Puerto Suelo (B) sites. $30 \mathrm{~m}$ resolution digital elevation model derived from GeoMapApp. 


\section{Electromagnetic Induction (EMI) method}

\subsection{BASIC THEORY}

Among the electromagnetic methods used for paleoseismological purposes, the electromagnetic method at low induction numbers (EMI), allows us characterizing the horizontal variation of apparent electrical conductivity, at a fixed depth level. This methodology is useful because of the relative easiness and quickness in data acquisition and processing (McNeill, 1980; Beamish, 2011).

This method is classified into the frequency domain and consists of a transmitter, which generates an electromagnetic field by the flow of alternating current in the coil according to Faraday's law. This magnetic field induces currents, which interact with the ground. In turn, these eddy currents generate a secondary magnetic field. The superposition of both fields, the one induced by the transmitter and the second one generated by its interaction with the conductive subsoil, are measured on a receiver coil. However, these measurements must satisfy the condition of operating at low-induction numbers (i.e. induction assumption is ruling, and the penetration depth is depending on the array geometry and coils spacing) to establish a relatively simple relationship between the secondary field and the subsoil conductivity. This relationship depends not only on the induced field measured in the receiver but also on parameters as the separation between transmitter and receiver coils and the transmitting frequency, which guarantees the low-induction number condition. Thus, according to Beamish (2011) the ratio of coupling between the primary and secondary fields can be written as:

$$
\left(\frac{H_{s}}{H_{p}}\right)=\frac{i \omega \mu_{0} \sigma s^{2}}{4}
$$

Where $H_{p}$ is the primary magnetic field, $H_{s}$ the secondary field, $\omega$ the angular frequency, $\mu_{0}$ the magnetic permeability of vacuum, $\sigma$ the electrical conductivity, and $s$ is the coils spacing. This ratio is a complex number, which can be separated into a real part and imaginary part, also called in-phase and in quadrature, respectively. Thus, the in-quadrature component is proportional to the conductivity of the medium and the in-phase component is proportional to the magnetic susceptibility, so it will provide relevant information on the magnetic characteristics of the subsoil.

The main advantage of this electromagnetic technique is that data acquisition and interpretation can be done in a very easy way. If we only use a constant spacing between coils, it is possible to obtain a horizontal section of the distribution of the apparent conductivity at a constant depth controlled by the subsoil electrical conductivity. As already mentioned, we can measure two different parameters using EMI: apparent conductivity or apparent resistivity and the called in phase parameter, measured in parts per thousand (ppt), which is related to the magnetic susceptibility of the subsoil.

Data acquisition consists of moving the sensors on the ground, with a constant distance between them either in a pattern of horizontal or vertical coplanar coils. Measured quantities depend on a volume of subsurface located under and between the two coils. The measure is assigned to the mid-point and an average depth for visualization purposes. Thus, measurements can be acquired in a continuous mode.

None additional processing is required to generate horizontal distribution maps for these parameters but the elimination of values that deviate from normal variation ranges established during instrument calibration. From the results, the distribution maps of the apparent conductivity or resistivity and in-phase at a constant depth (i.e. depending the spacing of the coils) can be generated using a simple interpolation process.

\subsection{EMI STUDY AREA: THE TEMASGALGINGO SITE}

The Temascalcingo site is located at the border of the Temascalcingo city, at the intersection 
between the Lerma river and the Temascalcingo fault, a $21 \mathrm{~km}$ long fault zone that trends in an $\mathrm{N} 120^{\circ}$ direction and extends from the top of the Temascalcingo Volcano to the eastern foot of the Altamirano volcano (Lacan et al., 2013b; Sunye-Puchol et al., 2015; Lagunas Ocon 2017; Velazquez-Bucio and Garduño-Monroy, 2018; Ortuño et al., 2019, Figure 3). Ruptures along part of the Temascalcingo fault during the Acambay earthquake of 1912 were reported by Urbina and Camacho (1913). However, at the Temascalcingo site, the alluvial plain is perfectly flat, and the location of the rupture is poorly described in the historical document and only refers as "roughly East-West fractures, (...) north of the iron bridge" (Urbina and Camacho, 1913). The topographic imprint of the fault is clear in the Temascalcingo and the Bañi volcanic edifices but erased by flooding which regularly reshapes the surface of the floodplain of the Lerma river (Figure 4).
In the Temascalcingo Site, the current sediments of the floodplain of the Lerma river overlap discontinuously the dacitic volcanic rocks of Temascalcingo and Bañi volcanic edifice in the footwall of the fault while the thickness of the alluvial filling in the hanging wall could be several tens of meters (Sánchez-Rubio, 1984; Aguirre-Díaz et al., 2000; Roldan-Quintana et al., 2011).

We focused on identifying at this site the precise location of the Temascalcingo fault buried under the floodplain of the Lerma river on which the city of Temascalcingo is now expanding.

\subsection{EMI SURVEY, RESULTS AND INTERPRETATION OF THE MAPS}

The EMI data acquisition was performed during October 2016, using a conductivity meter of GF Instruments. The spacing between coils was chosen equal to $2 \mathrm{~m}$ in order to reach a maximum

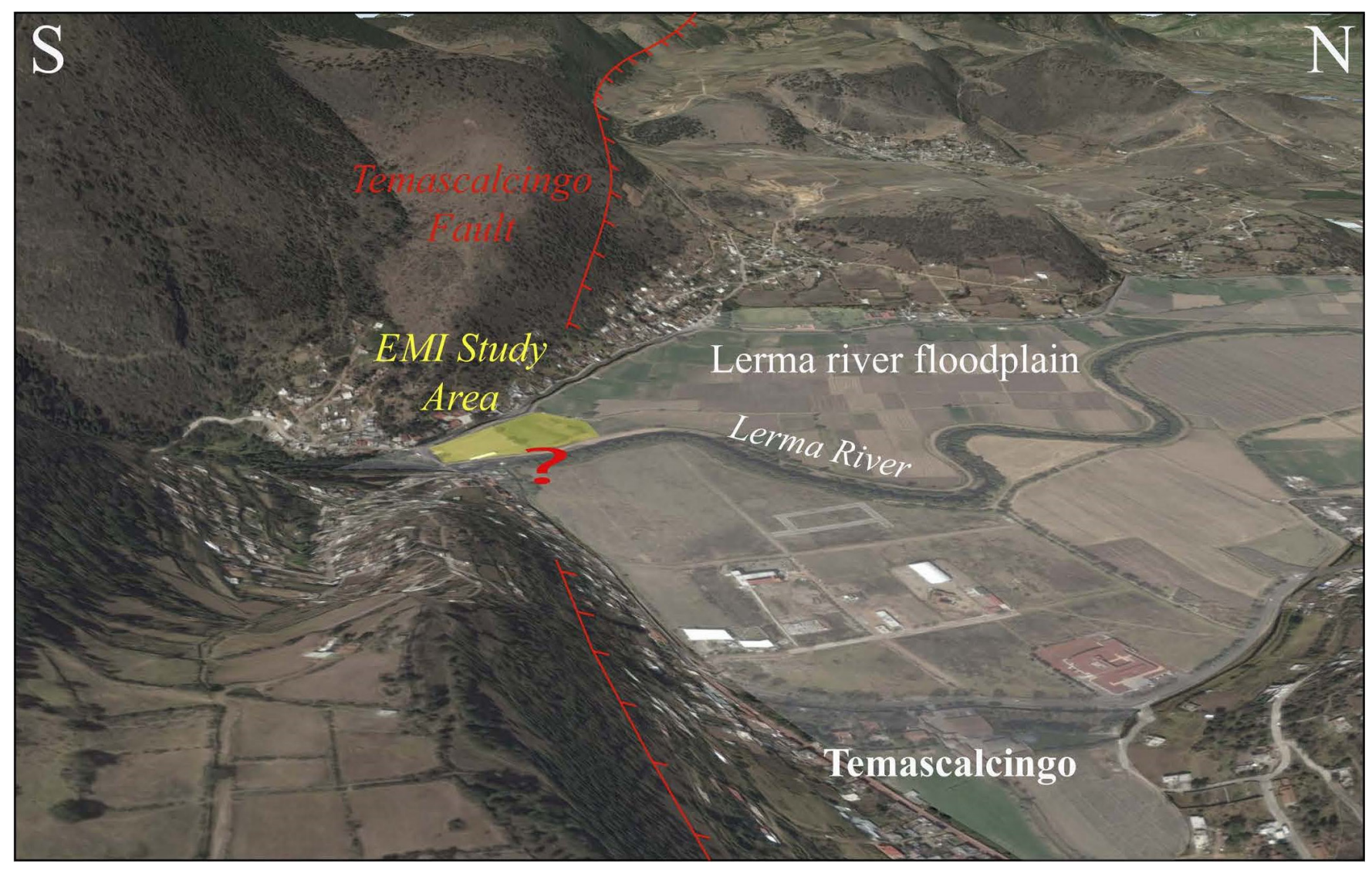


investigation depth of $3.2 \mathrm{~m}$ according to estimation based on the assumption that the maximum investigation depth is reached when the total current flowing in the region between the surface and the plane at depth is about 70\% (e.g. McNeill, 1980; Sudduth et al., 2001; Callegary et al., 2007; Saey et al., 2011, 2012; Smedt et al., 2012). A Magellan ProMark 3 RTK GPS was attached to the EMI acquisition system in order to obtain continuous and higher precision coordinates of each measured point. Data processing consisted of removing any isolated data out of the expected range since a calibration procedure was performed at the very beginning of the measurement. After this data clean-up, an interpolation procedure was computed in Surfer from Golden Software in order to show the horizontal variation of the apparent resistivity and the in-phase parameter (Figure 5).
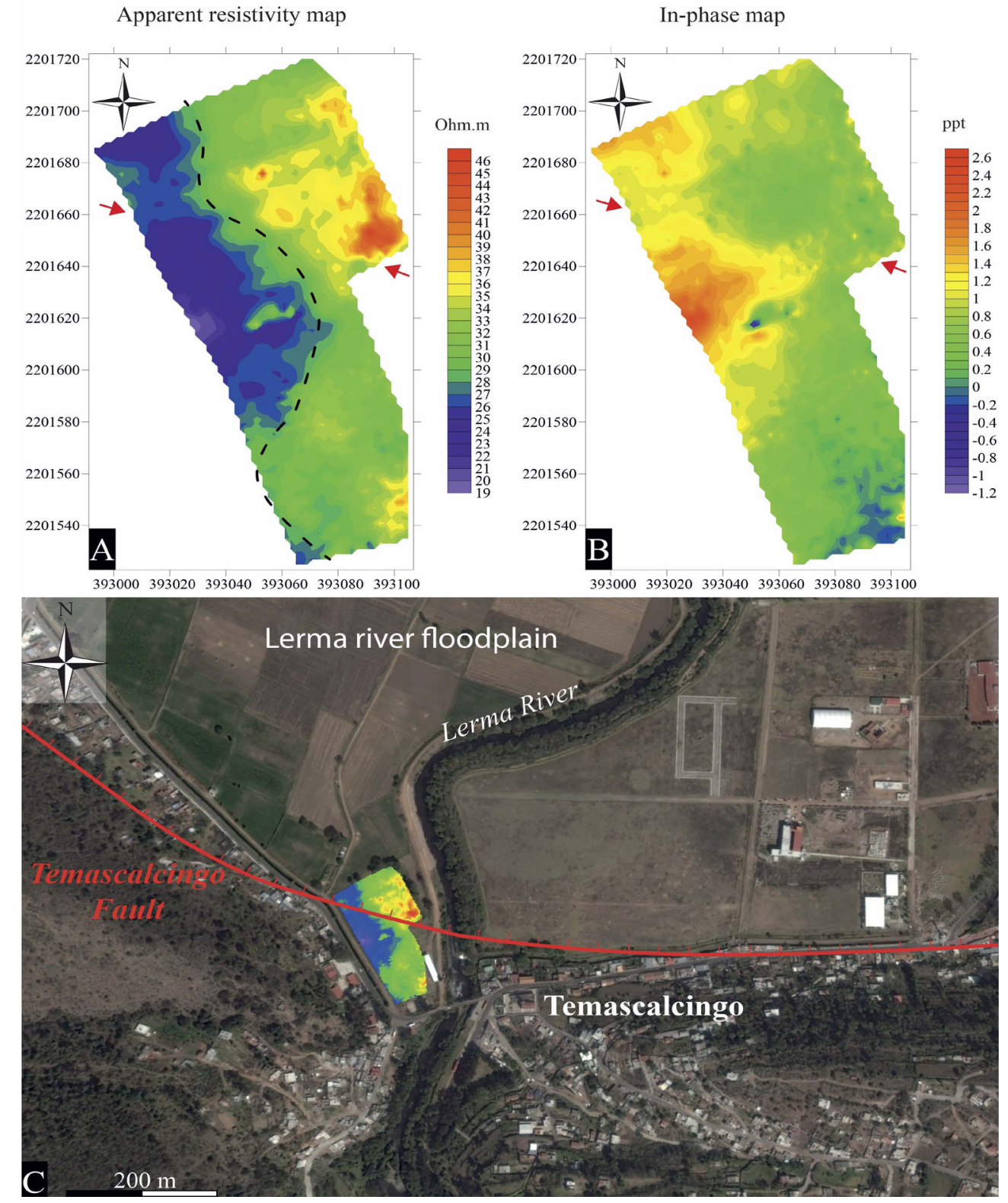

Figure 5 A) Apparent resistivity and B) in-phase component horizontal maps inferred from EMI technique performed at the Temascalcingo site. The red arrows indicate the orientation of the main lineament marked on the two images by an increased gradient. C) Precise location of the Temascalcingo fault trace around Temascalcingo city interpreted from the present EMI study. 
Figures $5 \mathrm{~A}$ and $5 \mathrm{~B}$ show the horizontal variation of apparent electrical resistivity and in-phase component. It is possible to appreciate slight contrasts of resistivity and in-phase that determine slight curve and lineament. The slight curve is oriented NNW-SSE, almost parallel to the river channel (black dashed line on Figures 5A and 5B) and corresponds to a contact between a conductive unit (to the west) and a more resistive unit (to the east). Considering the orientation and the meandering geometry of this curve, it is interpreted as a contact between the conductive volcanic bedrock and resistive alluvial filling of a paleovalley buried under the Temascalcingo alluvial plain. In contrast, the lineament is oriented WNW-ESE, almost perpendicular to the river course (red arrows on Figures $5 \mathrm{~A}$ and $5 \mathrm{~B}$ ). These contrast results from the differences of electromagnetic properties of the lithology at depth. For its linearity and orientation, we can infer that this high gradient corresponds to the contact between conductive sediments, resulting from the erosion of the volcanic bedrock of the footwall, and relatively resistive alluvial and lacustrine sedimentary filling of the hanging wall. This difference in resistivity could be the result of the fault displacement across the Quaternary deposits of the Lerma river. This behaviour is confirmed by the in-phase component, since a higher magnetic susceptibility values are expected from volcanic-origin materials (Figure 5B).

\section{Electrical Resistivity Tomography (ERT) method}

\subsection{BASIC THEORY}

In the subsoil, the electrical resistivity is influenced by many parameters like composition, texture, saturation, porosity, permeability, cracks or faults (e.g. Meju, 2002). In this sense, surveying this property could be useful to detect lateral discontinuities that could be related to the occurrence of a fault that has been covered by recent sediments.

The most common methods for measuring the resistivity distribution within the subsurface are those where the current is transmitted into the subsoil mainly by galvanic contact (i.e. direct current). For these measurements, a direct current is injected between a pair of electrodes, and the response generated by this current is measured through the potential established on the subsurface (Keller and Frischknecht, 1966).

$$
r=K \frac{U}{I}[\mathrm{~W} . m]
$$

Where $K$ is the geometric factor which will depend on the electrode arrangement, $U$ is the potential and $I$ is the injected current.

Electrical resistivity tomography is a useful exploration technique to generate images of the subsurface distribution of the electrical resistivity based on measurement of the mentioned electrical potential in many points along a profile. The generated images are sections or volumes showing the resistivity distribution, which may be associated with geological structures or discontinuities (Griffiths et al., 1990; Griffiths and Barker, 1993). The acquisition procedure consists of a multi-electrode system where measurements are made simultaneously switching injection and potential electrodes along a profile. Subsequently, these measurements are modeled using an inversion algorithm to estimate the resistivity parameters. The inversion does not provide the true value of the subsoil resistivity but an estimation, and the solution is not unique since it depends on the regularization operator that is used.

\subsection{ERT STUDY AREA: THE PUERTO SUELO SITE}

The Puerto Suelo site is located at the top of the Temascalcingo volcano, along the San Pedro fault, a 14-km-long fault zone that trends in an $\mathrm{N} 120^{\circ}$ direction and extends from the Santa Lucía dome to the east to the Lerma river floodplain, north of Temascalcingo city, to the west (Figures. 1, 3 and 6). The Puerto Suelo site corresponds to a small endorheic basin generated by the closure of a valley by the San Pedro fault (Figure 6). Consequently, by moving the basement, the fault plane 
corresponds to a sharp contact between the volcanic rocks of the footwall and the sedimentary filling of the hanging wall (Figure 6C). Although on surface the valley is covered and partially filled by colluvial and alluvial deposits, a trench was dug in the sediments of the endorheic basin to study the paleoseismology of the San Pedro fault (Figure 6D; Lagunas Ocon, 2017).
The trench is $24 \mathrm{~m}$ long, $6 \mathrm{~m}$ wide and up to 6 $m$ deep. The sedimentary record exposed corresponds to an alternation of ash and pumice levels (mostly secondary volcaniclastic deposits), paleosols, debris flow, and wind and lake deposits. At the bottom of the trench the alternation of interspersed levels of ash, pumice and paleosols are displaced $65 \mathrm{~cm}$ by a vertical fault while the

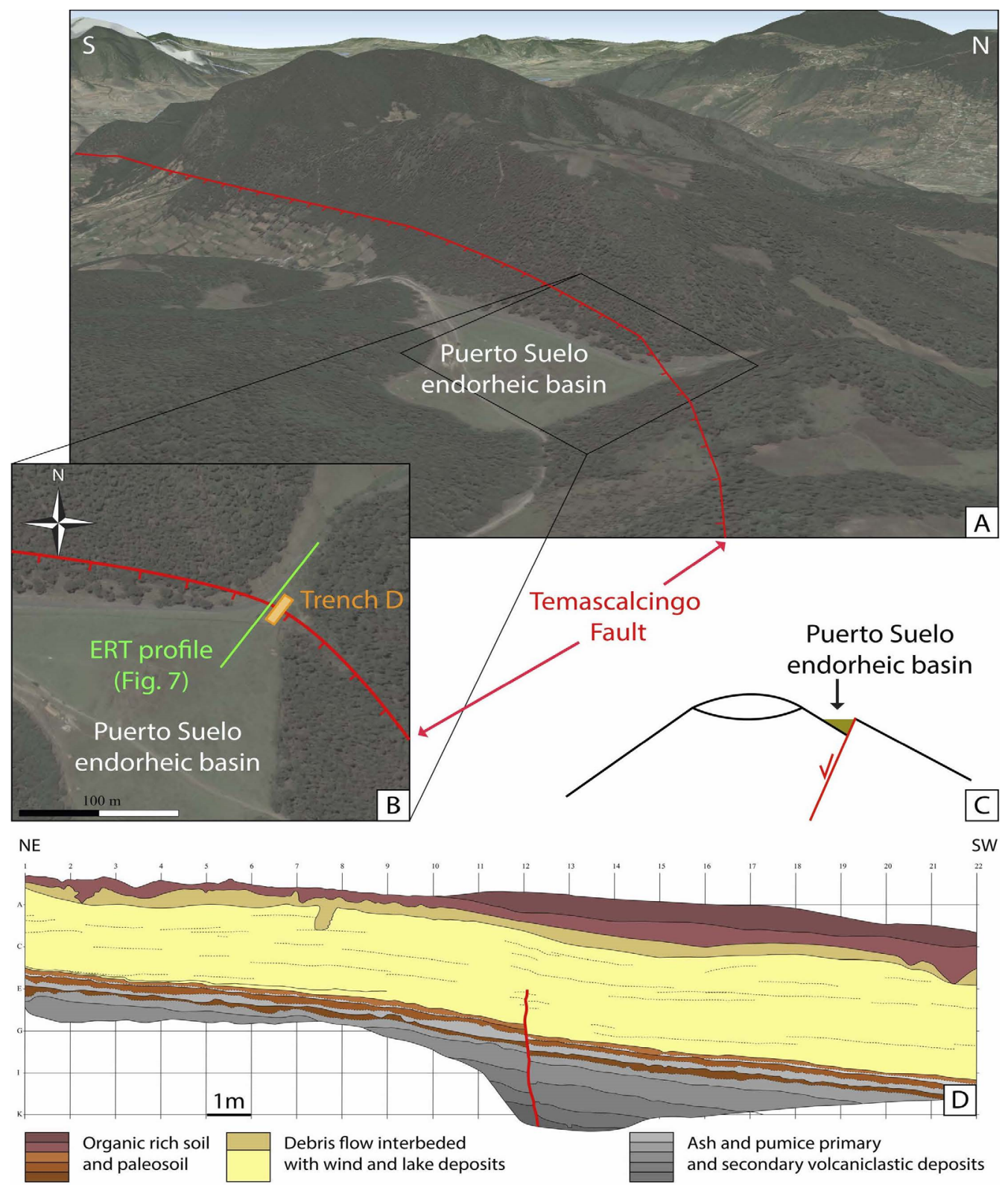

Figure 6 A) Google Earth 3D model of the Puerto Suelo site (Source Google Earth), B) aerial view of the Puerto Suelo site showing the location of the Puerto Suelo trench illustrated in D and the resistivity profile, C) diagram illustrating the endorheic basin of tectonic origin, D) Trench log of the Puerto Suelo trench as interpreted by Lagunas Ocon (2017). 
upper units record the same displacement along a fault propagation folds (Lagunas Ocon, 2017). Only one event, associated with a displacement of $65 \mathrm{~cm}$, was recorded in this trench, so there is not a significant lithological contrast between the two blocks separated by the fault on the scale of the trench (the first 4 to $5 \mathrm{~m}$ of the ground). However, at depth, the cumulative displacements over several seismic cycles could have brought into contact the massive andesitic rocks forming the volcanic edifice (basement) and the sedimentary filling of the endorheic basin.

The main objective in this site was to verify the dip of the structure at depth and estimate the depth of the basement under the sedimentary cover.

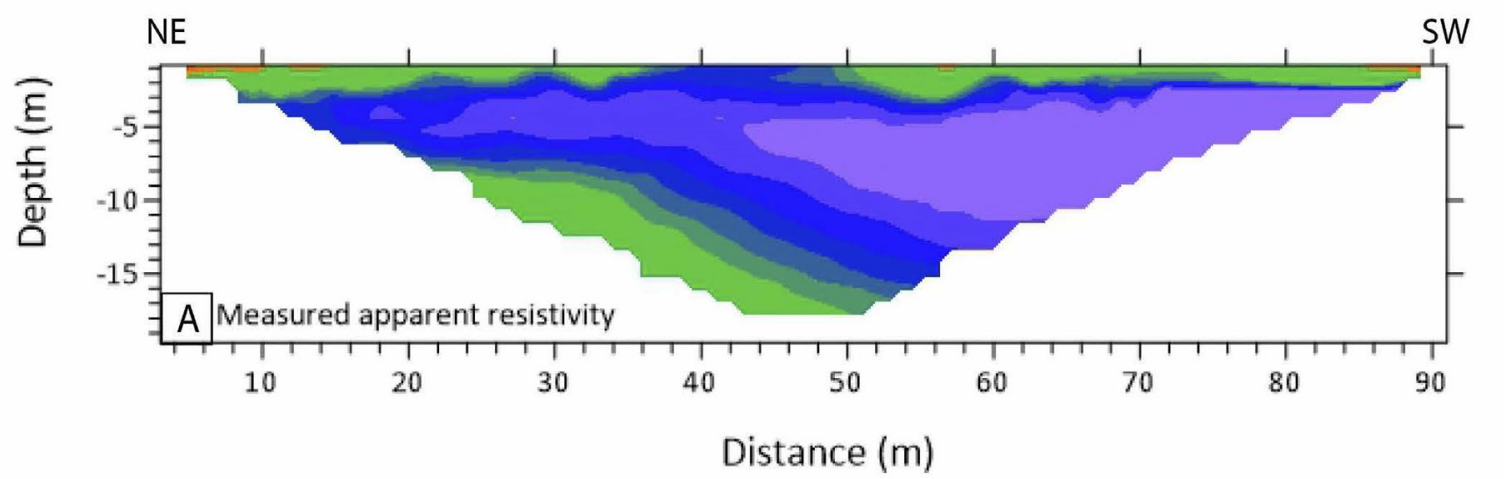

Ohm.m
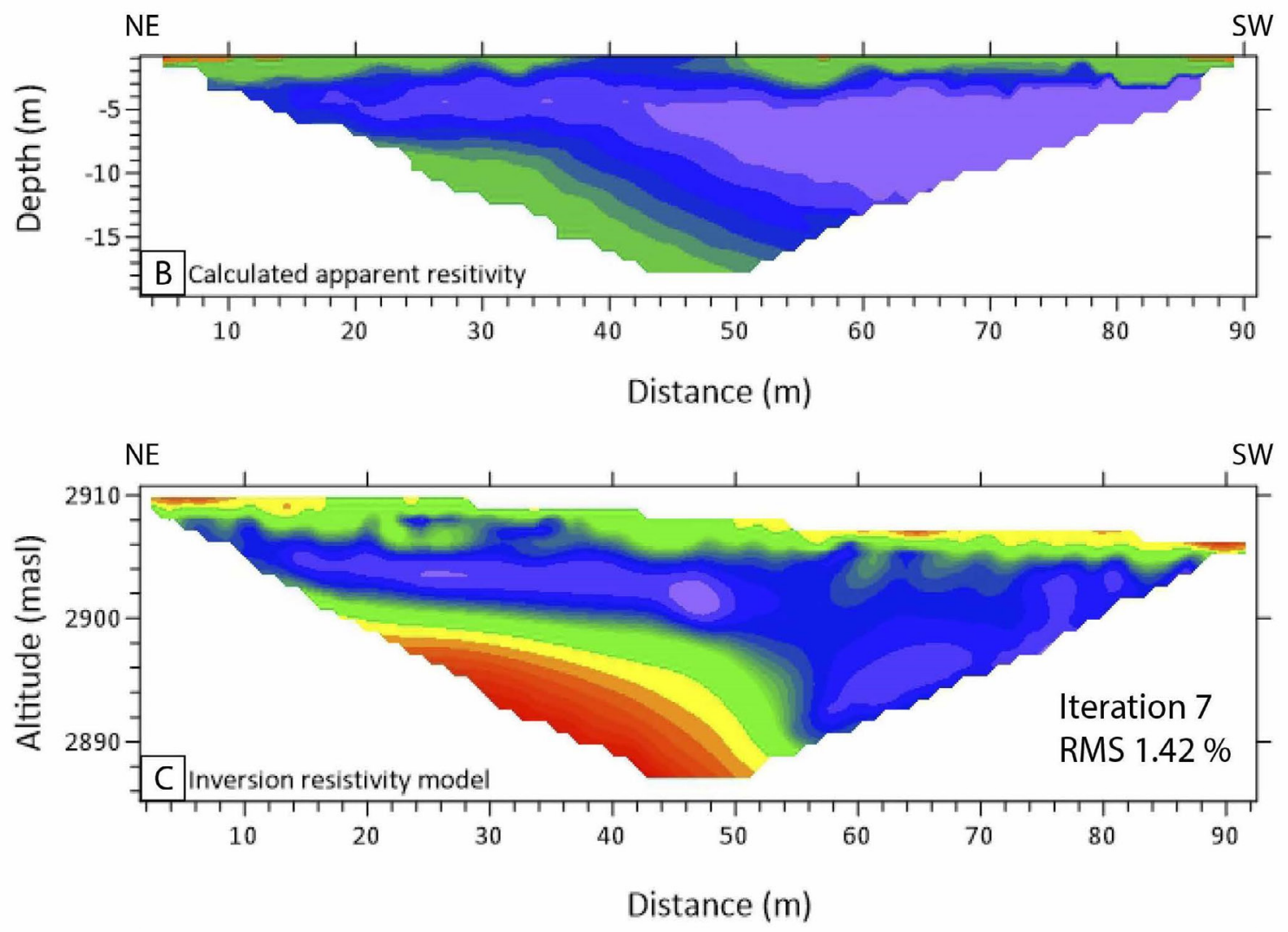

Figure 7 Resistivity distribution image inferred from ERT measured at the Puerto Suelo site, close to the top of the Temascalcingo Volcano: (A) measured apparent resistivity section, (B) calculated apparent resistivity section, (C) Inverted resistivity model. 


\subsection{ERT SURVEY, MODELING AND INTERPRETATION}

Regarding ERT, a $92 \mathrm{~m}$ length profile was measured coinciding with the trace of the paleoseismological trench already reported in Lagunas Ocon (2017). The ERT profile was acquired during October 2016, using a SYSCAL PRO device from Iris Instruments. The selected ERT array was dipole-dipole since it shows good sensitivity both in vertical and horizontal resistivity variations (Loke, 2014). Electrode spacing was of $2 \mathrm{~m}$ in order to have enough horizontal resolution to detect any lateral change generated by the presence of the fault. In total, 47 electrodes were involved, the injected current was set variable in one second cycles, in order to guarantee a potential value around $50 \mathrm{mV}$. In Figure 7, the typical resistivity outputs from the inversion scheme are shown. You can note that measured and calculated apparent resistivity are very similar, since the rms is 1.42. This means that the response from the inverted model is capable of closely reproducing the measured values during acquisition. ERT modeling was computed using the RES2DINV inversion algorithm based on a quasi-Newton scheme (Loke and Barker, 1996) to image the electrical resistivity variations along the profile up to $22 \mathrm{~m}$ depth. Also, a very accurate topographical control of each electrode position was included in the inversion process since the vertical variations could include errors in the geometry of the resistivity anomalies (e.g. Fox et al., 1980; Tsourlos et al., 1999).

Figure $7 \mathrm{C}$ shows a relatively uniform resistivity gradient, from 100 to $500 \mathrm{Ohm} . \mathrm{m}$, over the entire profile between the surface and almost $3 \mathrm{~m}$ depth (orange to green layers in Figure $7 \mathrm{C}$ ). Beneath this horizon, a strong lateral contrast is evident. The northeastern part of the profile is characterized

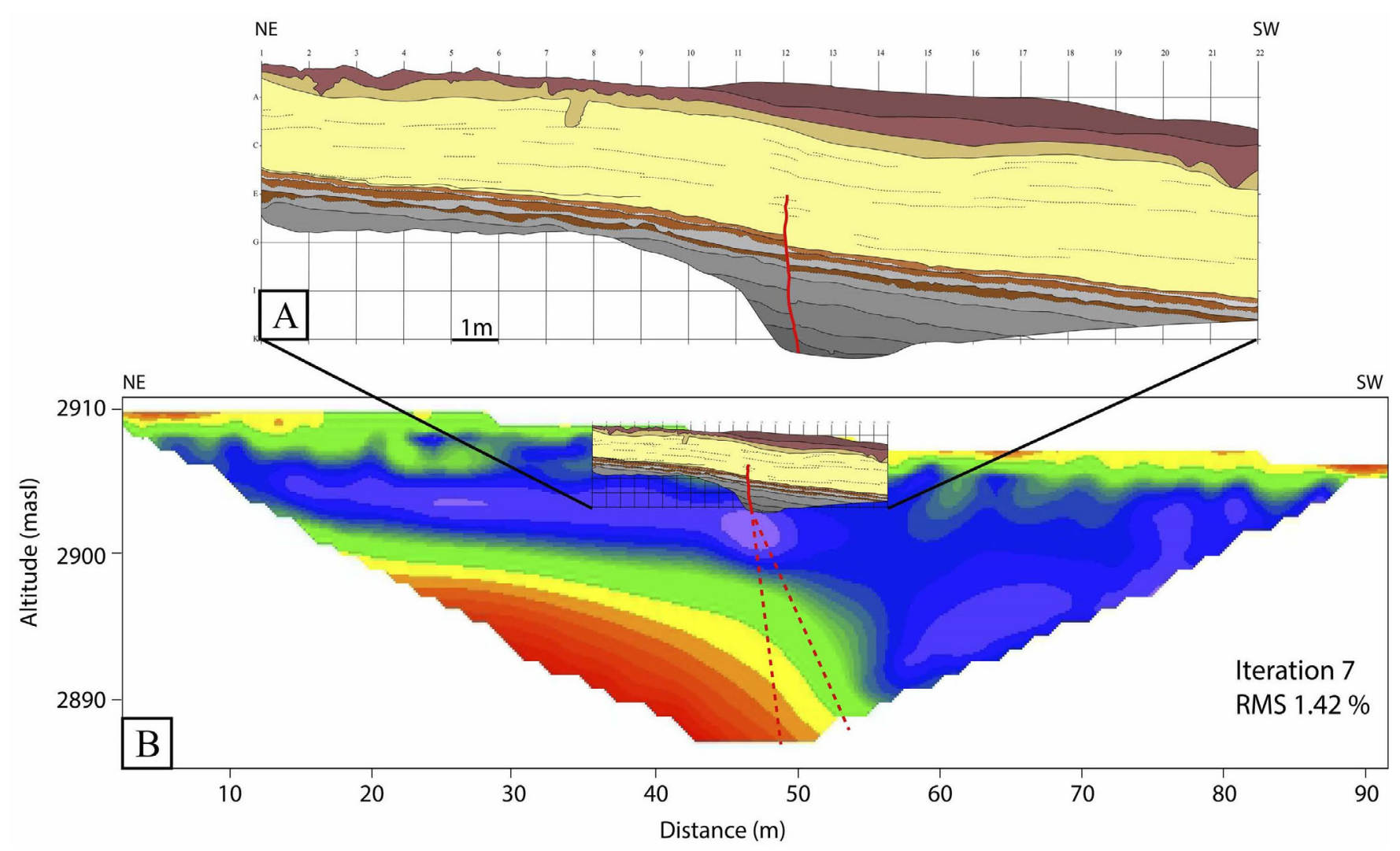

Figure 8 (A) Overlay data from the trench log of the Puerto Suelo trench as interpreted by Lagunas Ocon (2017), see Figure 6 and text for legend and interpretation. (B) Present ERT study across the San Pedro Fault. Location of the profile and trench in figure 6B. The two red dashed lines represent the maximum and minimum dips of the fault calculated from the profile. See figure 7 for legend. 
by lower resistivity values ranging from 10 to 40 Ohm.m between 3 and $9 \mathrm{~m}$ deep (purple to blue layers in Figure $7 \mathrm{C}$ ) and then, the resistivity values gradually increase to reach about 600 Ohm.m beneath $20 \mathrm{~m}$ depth (yellow to red layers in Figure $7 \mathrm{C})$. This feature is inferred from central portion of the profile, where the geometrical array allowed measuring several attribution points calculated for the distal quadrupoles at depth. In contrast, this conductive feature dramatically changes about $50 \mathrm{~m}$ fiducial, where a strong lateral resistivity contrast is detected. In the southwestern block, beneath $9 \mathrm{~m}$ depth, instead of a resistive region, a conductive feature is detected showing resistivity values lower than 40 Ohm.m (purple to blue layers in Figure 7G). This discontinuity (represented in Figure 8) could be related to the displacement originated by the fault that put in contact two different lithological units showing different electrical resistivity. Thus, this profile allows us tracking the fault up to $20 \mathrm{~m}$ deeper than the bottom of the paleoseismological trench.

\section{Discussion and conclusions}

On the Temascalcingo site the Electromagnetic Induction method allows tracking and defining the location of the 1912 rupture along the Temascalcingo fault trace under the Lerma river floodplain (Figure 5G). The precise location and geometry of the fault provide essential information for future paleoseismological trenching. On the other hand, the location of this fault under the city of Temascalcingo has direct consequences for the assessment of the subsidence and seismic hazard and should be taken into account in urban development planning. Indeed, the destruction of the town of Temascalcingo during the 1912 earthquake reminds us of the risk that this fault represents. Due to its superficial location under the city, even a moderate earthquake $(\mathrm{Mw}>$ 4.5) could cause significant damage as shown, for example, during the 11 May 2011, 5.1 Mw Lorca earthquake or more recently during the Teil earthquake (Martinez-Díaz et al., 2012a, 2012b; Ritz et al., 2020). In addition to the seismic hazard associated with the activity of the fault, the contrast in lithology on both sides of the fault could be the cause of other geological hazards. Indeed, the difference in compaction between the lithologies located on both sides of the fault could be at the origin of ground deformations caused by groundwater over exploitation as commonly observed in the region (e.g. Figueroa Miranda et al., 2018; Carrera-Hernandez et al., 2021). In the same way, the sedimentary accumulation of unconsolidated and water-saturated materials over several tens or even hundreds of meters can localize significant seismic amplification, or site effect, as observed for example in Mexico City (Singh et al., 2018; Mayoral et al., 2019). In this case, even a distant earthquake could have disastrous consequences for the part of Temascalcingo built on the sedimentary filling.

The generalization of such studies for urban planning could allow better management of resources, infrastructures and potentially save many lives.

On the Puerto Suelo site the trench dug to study the paleoseismic activity of the San Pedro fault shows the same fluvio-lacustrine units on either side of the fault, simply displaced by a few tens of centimeters. The volcanic bedrock does not appear in the trench and the fault appears to be vertical in the first four meters of basement exposed (Figures $6 \mathrm{D}$ and 8 ). The vertical geometry of the fault in the trench may be related to the relaxation of vertical stresses and do not represent the actual dip of the fault at depth (McCalpin, 2009; Chapter 3). The possibility of imaging the first $25 \mathrm{~m}$ of the structure and estimating its inclination is an important result to take into account in characterizing the geometry of the fault, its relationship with neighboring faults and indirectly, estimating its seismogenic potential. Extrapolation of the fault observed in the trench using the contrasts visible on the geoelectrical profile at approximately $50 \mathrm{~m}$ fiducial and beneath $3 \mathrm{~m}$ depth, indicates that the fault has a strong dip towards the south (70 to $80^{\circ} \mathrm{SW}$ ), compatible with the topographic 
escarpment visible in the morphology east and west of Puerto Suelo (Figure 6A). The electrical profile also shows that the fluviolacustrine filling of the basin (<40 Ohm.m, Figures 7 and 8$)$ is quite important with $10 \mathrm{~m}$ of thickness in the footwall and at least $20 \mathrm{~m}$ in the hanging wall. Below, in the footwall, the volcanic base is revealed on the profile showing lower conductivity values. In the Puerto Suelo site, it confirms that filling sediments overlying the basement are mostly saturated materials, since resistivity values are lower than $40 \mathrm{Ohm} . \mathrm{m}$. The footwall is showing resistivities ranging from 100 to 600 Ohm.m, suggesting the presence of a very dense and unaltered volcanic basement. It is important to note that such technique could also be useful to locate potential excavation sites when morphological traces of the fault are not clear or fully evident on the surface.

These two geophysical techniques, inexpensive and easy to set up along large distances and areas, could be used before trenching to localise the faults or to extrapolate local scale observations of the trench. These tools are particularly interesting in sites where a large fault zone (with various fault segments) is expected and where the local scale of the trench is not sufficient to integrate all the necessary observations to establish a proper paleoseismological interpretation. About the knowledge of superficial ruptures, these two methods made it possible to locate the trace of faults, despite they are buried by younger sediments, to obtain information on the geometry of the rupture and to have a first approach of the characteristics of the basement on either side of the fault. Finally, this study, associated with the excavation and interpretation of new trenches, will ultimately enable the rupture of the Acambay earthquake to be accurately mapped along the central faults of the graben.

\section{Acknowledgements}

The authors thank José Luis Salas Corrales and Diego Ruíz Aguilar for their valuable help during fieldwork. This study was funding by UNAM
DGAPA-PAPIIT program through IA101615 and IN108220 projects. This manuscript was greatly improved by comments and suggestions from three anonymous reviewers, Laura Perucca and Franck Audemard, invited editors of this issue.

\section{References}

Abe,K., 1981,Magnitudeof largeshallowearthquakes from 1904 to 1980: Physics of the Earth and Planetary Interiors, 27, 72-92. https://doi. org/10.1016/0031-9201(81)90088-1

Aguirre-Díaz, G.J., Urútia-Fucugauchi, J., Soler-Arechalde, MS., McDowell, F.W., 2000, Stratigraphy, K-Ar ages, and magnetostratigraphy of the Acambay graben, central Mexican Volcanic Belt, In DelgadoGranados, H., Aguirre-Díaz, G.J., Stock, J., (eds.), Cenozoic Tectonics and Volcanism of Mexico: Geological Society of America Special Paper, 334, 167-178. https://doi. org/10.1130/0-8137-2334-5.167

Aray Castellano, J.C., Lacan, P., Garduño Monroy, V.H., Ávila García, J., Gómez Cortés, J., Audemard Mennessier F., Lázaro Mancilla O., Bandy W., 2021, Geophysical characterization of a potentially active fault in the Agua Fría micro-graben, Los Azufres, México: Boletín de la Sociedad Geológica Mexicana, 73(2), A040121. http://dx.doi.org/10.18268/ BSGM2021v73n2a040121

Arzate, J., Lacan, P., Corbo-Camargo, F., ArangoGalván, C., Maldonado, R.F., Pacheco, J., León Loya, R., 2018, Deep structure of the eastern Acambay Graben (Central Mexico) from integrated geophysical data: Revista Mexicana de Ciencias Geológicas, 35-3, 228-239.

Audemard, F., Ollarves, R., Díaz, G., Bechtold, M., Cataldi, A., 2006, El geo-radar como herramienta para la definición de fallas activas: aplicación en el sector central de la falla de Boconó, Estado de Mérida, Venezuela: Revista de la Facultad de Ingeniería de la U.C.V., 21(4), 57-70. 
Beamish, D., 2011, Low induction number, ground conductivity meters: A correction procedure in the absence of magnetic effects: Journal of Applied Geophysics, 75, 244-253. https:// doi.org/10.1016/j.jappgeo.2011.07.005

Bonorino, G.G., Rinaldi, V., Del Valle Abascal, L., Alvarado, P., Bujalesky, G.G., Güell, A., 2012, Paleoseismicity and seismic hazard in southern Patagonia (Argentina-Chile; $50^{\circ}-55^{\circ} \mathrm{S}$ ) and the role of the MagallanesFagnano transform fault: Natural Hazards, 61 (2), 337-349. https://doi.org/10.1007/ s1 1069-011-9917-2

Callegary, J.B., Ferré, T.P.A., Groom, R.W., 2007, Vertical spatial sensitivity and exploration depth of low-induction-number electromagnetic-induction instruments: Vadose Zone Journal, 6, 158-167. https:// doi.org/10.2136/vzj2006.0120

Carrera-Hernández J., Levresse G., ArandaGomez J., Lacan P., 2021, Quantifying active deformation on a dry maar's bottom through a light unmanned aerial vehicle and Structure-from-Motion: International Journal of Remote Sensing, 42, 1, 20-38. https://doi.org/10.1080/01431161.2020.1 792574

Cinti, F.R., Pauselli, C., Livio, F., Ercoli, M., Brunori, C.A., Ferrario, M.F., Volpe, R., Civico, R., Pantosti, D., Pinzi, S., de Martini, P.M., Ventura, G., Alfonsi, L., Gambillara, R., Michetti, A.M., 2015, Integrating multidisciplinary, multiscale geological and geophysical data to image the Castrovillari fault (Northern Calabria, Italy): Geophysical Journal International, 203, 1847-1863. https://doi.org/10.1093/gji/ggv404

Demant, A., 1978, El Eje Neovolcanico Transmexicano; sus problemas de interpretacion: Revista Mexicana de Ciencias Geológicas, 2 (2), 172-187.

Fazzito, S.Y., Rapalini, A.E., Cortés, J.M., Terrizzano, G.M., 2009, Characterization of quaternary faults by electric resistivity tomography in the andean precordillera of western argentina:Journal of South American Earth Sciences, 28(3), 217-228. https://doi. org/10.1016/j.jsames.2009.06.001

Ferrari, L., Orozco-Esquivel, T., Manea, V., Manea, M., 2012, The dynamic history of the Trans-Mexican Volcanic Belt and the Mexico subduction zone: Tectonophysics, 522523, 122-149. https://doi.org/10.1016/j. tecto.2011.09.018

Figueroa-Miranda, S., Tuxpan-Vargas, J., Ramos-Leal, J. A., Hernández-Madrigal, V. M., Villaseñor-Reyes, G.I., 2018, Land subsidence by groundwater over-exploitation from aquifers in tectonic valleys of central mexico: A review: Engineering Geology, 246, 91-106. https://doi.org/10.1016/j. enggeo.2018.09.023

Fletcher, J.M., Teran, O.J., Rockwell, T.K., Oskin, M.E., Hudnut, K.W., Mueller, K.J., Spelz, R.M., Akciz, S.O., Masana, E., Faneros, G., Fielding, E.J., Leprince, S., Morelan, A.E., Stock, J., Lynch, D.K., Elliott, A.J., Gold, P., Liu-Zeng, J., González-Ortega, A., HinojosaCorona, A., González-García, J., 2014, Assembly of a large earthquake from a complex fault system: Surface rupture kinematics of the 4 April 2010 El Mayor-Cucapah (Mexico) Mw 7.2 earthquake: Geosphere, 10, 797-827. https://doi.org/10.1130/GES00933.1

Fletcher, J.M., Teran, O.J., Rockwell, T.K., Oskin, M.E., Hudnut, K.W., Spelz, R.M., Lacan, P., Dorsey, M.T., Ostermeijer, G., Mitchell, T.M., Akciz, S.O., Hernandez-Flores, A.P., Hinojosa-Corona, A., Peña-Villa, I., Lynch, D.K., 2020, An analysis of the factors that control fault zone architecture and the importance of fault orientation relative to regional stress: Geological Society of America Bulletin, 132 (9-10), 2084-2104. https://doi.org/10.1130/B35308.1

Fox, R.C., Hohman, G.W., Killpack, T.J., Rijo, L., 1980, Topographic effects in resistivity and induced-polarization surveys: Geophysics, 45(1), 75-93. https://doi. org/10.1190/1.1441041 
Galli, P., Piscitelli, S., 2014, Surface breaks along the coastal plain of Cirò (Ionian Calabria, southern Italy): Geophysical and paleoseismological insights: Natural Hazards, 71(1), 291-313. https://doi. org/10.1007/s1 1069-013-0914-5

Griffiths, D.H., Barker, R.D., 1993, Twodimensional resistivity imaging and modelling in areas of complex geology: Journal of Applied Geophysics, 29 (3-4), 211-226. https://doi. org/10.1016/0926-9851(93)90005-J

Griffiths, D.H., Turnbull, J., Olayinka, A.I., 1990, Two-dimensional resistivity mapping with a computer- controlled array: First Break, 8, 121-129. https://doi. org/10.3997/1365-2397.1990008

Johnson, G.A., Harrison, G.G.A., 1990, Neotectonics in central Mexico: Physics of the Earth and Planetary Interiors, 64, 187-210. https://doi. org/10.1016/0031-9201(90)90037-X

Keller, G.V., Frischknecht, F.C., 1966, Electrical methods in geophysical prospecting: Pergamon Press Inc., Oxford. 527 p.

La Femina, P.C., Connor, C.B., Stamatakos, J.A., Farrell, D.A., 2002, Imaging an active normal fault in alluvium by high-resolution magnetic and electromagnetic surveys: Environmental and Engineering Geoscience, 8(3), 193-207. https://doi.org/10.2113/8.3.193

Lacan P., Nivière B., Rousset D., Sénéchal P., 2012, Late Pleistocene folding above the Mail Arrouy Thrust, North-Western Pyrenees (France): Tectonophysics, 541543, 57-68. https://doi.org/10.1016/j. tecto.2012.03.022.

Lacan, P., Ortuño, M., Perea, H., Baize, S., Audin, L., Aguirre-Díaz, G., Zúñiga, F.R., 2013a, Upper Pleistocene to Holocene earthquakes recorded at the western termination of the Venta de Bravo fault system, Acambay graben (central Mexico), In Grützner C, Rudersdorf A, Pérez-López R, Reicherter K (eds.), Seismic Hazard, Critical Facilities and Slow Active Faults: Aachen, Germany,
Proceedings of the 4th International INQUA Meeting on Paleoseismology, Active Tectonics and Archeoseismology (PATA), 133-136.

Lacan, P., Zúñiga, F.R., Ortuño, M., Persaud, M., Aguirre-Díaz, G.J., Langridge, R.M., Villamor, P., Perea, H., Štěpančíková, P., Carreón, D., Cerca, M., Suñe Puchol, I., Corominas, O., Audin, L., Baize, S., Lawton, T.F., Rendón, A., 2013b, Paleoseismological history of the Acambay graben (central Mexico): Eos, Transactions, American Geophysical Union, 94, T23C-2591.

Lacan, P., Ortuño, M., Audin, L., Perea, H., Baize, S., Aguirre-Díaz, G., Zúñiga, F.R., 2018, Sedimentary evidence of historical and prehistorical earthquakes along the Venta de Bravo Fault System, Acambay Graben (Central Mexico): Sedimentary Geology, 365, 62-77. https://doi.org/10.1016/j. sedgeo.2017.12.008

Lagunas Ocon, A.D., 2017, Estudio paleosismológico de la falla San Pedro en el Graben de Acambay, Cinturón Volcánico Trans-Mexicano: Guerrero, México, Unidad Académica Regional de Ciencias de la Tierra de la Universidad Autónoma de Guerrero, Tesis de Licenciatura, 53p.

Langridge, R.M., Weldon, R.I., Moya, J.G., Suaréz, G., 2000, Paleoseismology of the 1912 Acambay earthquake and the Acambay-Tixmadejé Fault, Trans-Mexican Volcanic Belt: Journal of Geophysical Research, 105 (B2), 3019-3037. https://doi. org/10.1029/1999JB900239

Langridge, R.M., Persaud, M., Zúñiga, F.R., Aguirre-Díaz, G.J., Villamor, P., Lacan, P., 2013, Preliminary paleoseismic results from the Pastores Fault and its role in the seismic hazard of the Acambay graben, TransMexican Volcanic Belt, Mexico: Revista Mexicana de Ciencias Geológicas, 30(3), 463-481.

Loke, M.H., 2014, Tutorial: 2-D and 3-D electrical imaging surveys. Revised version: www.geotomosoft.com (accessed November 23, 2020). 
Loke, M.H., Barker, R.D., 1996, Rapid leastsquares inversion of apparent resistivity pseudosections by a quasi-Newton method: Geophysical Prospecting, 44(1), 131-152. https://doi.org/10.1111/j.1365-2478.1996. tb00142.x

Martínez-Díaz, J.J., Masana, E., Ortuño, M., 2012a, Active tectonics of the Alhama de murcia fault, Betic Cordillera, Spain: Journal of Iberian Geology, 38-1, 269-286. http:// dx.doi.org/10.5209/rev_JIGE.2012.v38. $\mathrm{n} 1.39218$

Martínez-Díaz, J.J., Bejar-Pizarro, M., ÁlvarezGómez, J.A., Mancilla, FdL, Stich, D., Herrera, G., Morales, J., 2012b, Tectonic and seismic implications of an intersegment rupture: The damaging May 11th $2011 \mathrm{Mw}$ 5.2 Lorca, Spain, earthquake: Tectonophysics 546-547, 28-37. https://doi.org/10.1016/j. tecto.2012.04.010

Mayoral, J.M., Asimaki, D., Tepalcapa, S., Wood, C., Roman-de la Sancha, A., Hutchinson, T., Franke, K., Montalva, G., 2019, Site effects in Mexico City basin: Past and present: Soil Dynamic Earthquake Engienering; 121 (March): 369-82. http://dx.doi. org/10.1016/j.soildyn.2019.02.028.

McCalpin, J.P., 2009, Paleosesmology (second edition): Amsterdam, Academic PressElsevier, $848 \mathrm{p}$.

McNeill, J.D., 1980, Electromagnetic terrain conductivity measurements at low induction numbers: Technical Note TN-6, Geonics Limited. Mississauga, ON, Canada.

Meju, M.A., 2002, Geoelectromagnetic exploration for natural resources: Models, case studies and challenges: Surveys in Geophysics, 23, 133-205. https://doi. org/10.1023/A:1015052419222

Nguyen, F., Garambois, S., Jongmans, D., Pirard, E., Loke, M.H., 2005, Image processing of 2D resistivity data for imaging faults: Journal of Applied Geophysics, 57(4), 260-277. https:/ / doi.org/10.1016/j.jappgeo.2005.02.001.

Nguyen, F., Garambois, S., Chardon, D., Hermitte, D., Bellier, O., Jongmans, D., 2007,
Subsurface electrical imaging of anisotropic formations affected by a slow active reverse fault, Provence, France: Journal of Applied Geophysics, 62, 338-353. https://doi. org/10.1016/j.jappgeo.2007.03.003

Nixon, G.T., 1982, The relationship between Quaternary volcanism in central Mexico and the seismicity and structure of subducted ocean lithosphere: Geological Society of America Bulletin, 93, 514-523. https://doi. org/10.1130/0016-7606(1982)93<514:TRB QVI>2.0.CO;2

Onorato, M.R., Prezzi, G., Orgeira, M., Perucca, L., Coronato, A., López, R., Magneres, I., 2019, Geophysical characterization of Udaeta Lake as a possible pull-apart basin associated to quaternary tectonic activity along Magallanes-Fagnano fault system: Quaternary International, 523, 67-79. https://doi.org/10.1016/j. quaint.2019.06.025

Ortuño, M., Zúñiga, F.R., Aguirre-Díaz, G.J., Carreón-Freyre, D., Cerca, M., Roverato, M., 2015, Holocene paleo-earthquakes recorded at the transfer zone of two major faults: the Pastores and Venta de Bravo faults (Trans- Mexican Volcanic Belt): Geosphere, 11 (1), 160-184. https://doi.org/10.1130/ GES01071.1

Ortuño, M., Corominas, O., Villamor, P., Zúñiga, F.R., Lacan, P., Aguirre-Díaz, G., Perea, H., Štěpančíková, P., Ramírez-Herrera, M.T., 2019, Evidence of recent ruptures in the central faults of the Acambay Graben (central Mexico): Geomorphology, 326, 17-37. https://doi.org/10.1016/j. geomorph.2018.07.010

Ritz, J-F., Baize, S., Ferry, M., Larroque, C., Audin, L., Delouis B., Mathot, E., 2020, Surface rupture and shallow fault reactivation during the $2019 \mathrm{Mw} 4.9 \mathrm{Le}$ Teil earthquake, France: Communications Earth and Environment, 1, 10. https://doi. org/10.1038/s43247-020-0012-z

Rodríguez-Pascua, M.A., Garduño-Monroy, V.H., Pérez-López, R., Perucha-Atienza, 
M.A., Israde-Alcántara, I., 2012, The Acambay earthquake of 1912, revisited 100 years after, In Pérez-López, R., Silva, P.G., Rodríguez-Pascua, M.A., Garduño-Monroy, V.H., Suárez, G., Reicherter, K. (eds.) Paleoseismology and archaeosesimology meeting: Morelia, Mexico, 3rd INQUAIGCP-567 International Workshop on Active Tectonics, Proceedings, 157-160.

Rodríguez-Pascua, M.A., Pérez-López, R., Garduño-Monroy, V.H., Perucha, M.A., Israde-Alcántara, I., 2017, Estimation of the epicentral area of the 1912 Acambay earthquake (M 6.9, Mexico) determined from the earthquake archaeological effects (EAE) and the ESI07 macroseismic scale: Quaternary International, 451, 74-86. https://doi.org/10.1016/j. quaint.2017.06.045

Rodriguez-Pérez, Q., Zúñiga, F.R., Lacan, P., 2017, Paleoseismological uncertainty estimation in the Acambay region, Central Mexico: Geofisica Internacional, 56-3, 255-268. https://doi.org/10.22201/ igeof.00167169p.2017.56.3.1816

Roldán-Quintana,J., Aguirre-Díaz, G., RodríguezCastañeda,J.L., 2011, Depósito de avalancha de escombros del volcán Temascalcingo en el graben de Acambay, Estado de México: Revista Mexicana de Ciencias Geológicas, 28, 118-131.

Saey, T., Van Meirvenne, M., Smedt, P., Cockx, L., Meerschman, E., Islam, M. M., Meeuws, F., 2011, Mapping depth-to-clay using fitted multiple depth response curves of a proximal EMI sensor: Geoderma, 162, 151-158. https://doi.org/10.1016/j. geoderma.2011.01.015

Saey, T., Smedt, P., Islam, M. M., Meerschman, E., Van De Vijver, E., Lehouck, A., Van Meirvenne, M., 2012, Depth slicing of multireceiver EMI measurements to enhance the delineation of contrasting subsoil features: Geoderma, 189-190, 514-521. https://doi. org/10.1016/j.geoderma.2012.06.010
Sánchez-Rubio, G., 1984, Cenozoic volcanism in the Toluca-Amealco region, central Mexico: Imperial College of Science and Technology, University of London, Ph.D. thesis, $275 \mathrm{p}$.

Siebe, C., Macías, J.L., Aguirre-Díaz, G.J., 2006, Neogene-Quaternary continental margin volcanism: A perspective from Mexico: Geological Society of America, Special Paper, 402, 329. https://doi.org/10.1130/ SPE402

Singh, S.K., Reinoso, E., Arroyo, D., Ordaz, M., Cruz-Atienza, V., Pérez-Campos, X., Iglesias, A., Hjörleifsdóttir, V., 2018, Deadly intraslab Mexico earthquake of 19 september 2017 (Mw7.1): Ground motion and damage pattern in Mexico City: Seismological Research Letters, 89, 6, 2193-2203. https:// doi.org/10.1785/0220180159

Smedt, P., Saey, T., Lehouck, A., Stichebaut, B., Meerschman, E., Islam, M. M., Van De Vijver, E., Van Meirvenne, M., 2012, Exploring the potential of multi-receiver EMI survey for geoarcheaological prospection: A 90 ha dataset: Geoderma, 199, 30-36. https://doi. org/10.1016/j.geoderma.2012.07.019

Stephenson, W.J., McBride, J.H., 2003, Contributions to neotectonics and seismic hazard from shallow geophysical imaging: Tectonophysics, 368, 1-5. https://doi. org/10.1016/S0040-1951(03)00226-9

Suárez, G., Caballero-Jiménez, G. V., NoveloCasanova, D.A., 2019, Active Crustal Deformation in the Trans-Mexican Volcanic Belt as Evidenced by Historical Earthquakes During the Last 450 Years: Tectonics, 38, 3544-3562. https://doi. org/10.1029/2019TC005601

Sudduth, K.A., Drummond, S.T., Kitchen, N.R., 2001, Accuracy issues in electromagnetic induction sensing of soil electrical conductivity for precision agriculture: Computers and Electronics in Agriculture, 31, 239-264. https://doi.org/10.1016/ S0168-1699(00)00185-X 
Sunye-Puchol, I., Lacan, P., Ortuño, M., Villamor, P., Audin, L., Zúñiga, F.R., Langridge, R.M., Aguirre-Diaz, G., Lawton, T., 2015, La falla San Mateo: Nuevas evidencias paleosismológicas de fallamiento activo en el graben de Acambay, México: Revista Mexicana de Ciencias Geológicas, 32(3), 361-376. http://dx.doi.org/10.22201/ cgeo.20072902e.2015.3.589

Suter, M., Quintero, O., López, M., Aguirre, G., Farrar, E., 1995, The Acambay graben: Active intra arc extension in the trans-Mexican volcanic belt, Mexico: Tectonics, 14, 12451262. https://doi.org/10.1029/95TC01930

Suter, M., Carrillo-Martínez, M., Quintero Legorreta, O., 1996, Macroseismic study of earthquakes in the central and eastern parts of the Trans-Mexican Volcanic Belt: Seismological Society of America Bulletin, 86, 1952-1963.

Suter, M., López-Martínez, M., Quintero-Legorreta, O., Carrillo-Martínez, M., 2001, Quaternary intra-arc extension in the central TransMexican Volcanic Belt: Geological Society of America Bulletin, 113(6), 693-703. https://doi. org/10.1130/0016-7606(2001)113<0693:QI AEIT>2.0.GO;2

Terrizzano, C. M., Fazzito, S. Y., Cortés, J. M., \& Rapalini, A. E., 2012, Electrical resistivity tomography applied to the study of neotectonic structures, northwestern precordillera sur, central andes of argentina: Journal of South American Earth Sciences, 34, 47-60. https://doi.org/10.1016/j. jsames.2011.10.002

Tsourlos, P.I., Szymanski, J.E., Tsokas, G.N., 1999, The effect of terrain topography on commonly used resistivity arrays: Geophysics, 64(5), 1357-1363. https://doi. org/10.1190/1.1444640
Urbina, F., Camacho, H., 1913, Zona Megaseismica Acambay-Tixmadeje, Estado de México: Instituto Geológico de México, Secretaria de Fomento, 230 pp.

Velázquez-Bucio, M.M., Garduño-Monroy, V.H., 2018, Soft-sediment deformation structures induced by seismic activity in the San Pedro el Alto area, Acambay graben, Mexico: Revista Mexicana de Ciéncias Geólogicas 35(1),28-40. https://doi.org/10.22201/ cgeo.20072902e.2018.1.530

Villani, F., Tulliani, V., Sapia, V., Fierro, E., Civico, R., Pantosti, D., 2015, Shallow subsurface imaging of the Piano di Pezza active normal fault (central Italy) by highresolution refraction and electrical resistivity tomography coupled with time-domain electromagnetic data: Geophysical Journal International, 203. 1482-1494. https://doi. org/10.1093/gji/ggv399

Villani, F., Sapia, V., 2017, The shallow structure of a surface-rupturingfaultinunconsolidated deposits from multi-scale electrical resistivity data: The 30 October $2016 \mathrm{Mw} 6.5$ central Italy earthquake case study: Tectonophysics, 771,628-644. https://doi.org/10.1016/j. tecto.2017.08.001

Wolf, L.W., Tuttle, M.P., Browning, S., Park, S., 2006, Geophysical surveys of earthquakeinduced liquefaction deposits in the New Madrid seismic zone: Geophysics, 71 (6), B223-B230. https://doi. org/10.1 190/1.2353801

Zúñiga, F.R., Lacan, P., Rodríguez-Pérez, Q, Márquez-Ramírez, V.H., 2020, Temporal and spatial evolution of instrumented seismicity in the Trans-Mexican Volcanic Belt: Journal of South American Earth Sciences 98, 102390. https://doi. org/10.1016/j.jsames.2019.102390 